\title{
Production and quality of Tifton 85 pastures overseeded with black oat: effects of irrigation and nitrogen fertilization
}

\section{Produção e qualidade de pastagens de Tifton 85 sobressemeadas com aveia preta: efeitos da irrigação e adubação nitrogenada}

\author{
João de Assis Farias Filho ${ }^{1 *}$; Fabiana Luiza Matielo de Paula²; Adalberto Luiz \\ de Paula ${ }^{3}$; Wagner Paris ${ }^{3}$; Fabrício Ghinzellit; Gustavo Henrique Arend ${ }^{4}$; Luis \\ Fernando Glasenapp de Menezes $^{3}$
}

\begin{abstract}
The objective of this work was to evaluate the effects of irrigation and nitrogen fertilization on the bromatological quality, forage production, and botanical and structural composition of Tifton 85 (Cynodon sp.) pastures overseeded with black oat (Avena strigosa). Four treatments were evaluated in a $2 \times 2$ factorial scheme (irrigated and non-irrigated $\times$ fertilized and non-fertilized), with three replicates, in a completely randomized design. In irrigated paddocks, the irrigation system was activated when the soil matric potential reached a value equal to, or higher than, $10 \mathrm{kPa}$ and $135 \mathrm{~kg} \mathrm{~N} \mathrm{ha}^{-1}$ was applied to fertilized paddocks, divided into four applications. The forage mass pre- and post-grazing, total forage production, and the botanical, structural, and bromatological composition of the pastures were evaluated. No interaction was observed between the irrigation and nitrogen fertilization factors for any of the variables and no significant differences were observed in forage mass between pre- and post-grazing or in Tifton leaf and stem percentages. Nitrogen fertilization had a significant effect on forage production, which was $2626.41 \mathrm{~kg}$ dry matter $(\mathrm{DM}) \mathrm{ha}^{-1}$ higher in fertilized pastures than in unfertilized pastures. In addition, fertilization resulted in a lower percentage of dead material $(6.66 \%)$, higher percentage of oat leaves $(30.84 \%)$, higher leaf:stem ratio (1:45), higher crude protein content $(24.13 \%)$, lower levels of neutral detergent fiber (NDF) (64.57\%) and acid detergent fiber (ADF) (32.86\%), and higher in vitro dry matter digestibility $(73.01 \%)$ than in unfertilized pastures. The use of irrigation did not influence total forage production, however, it resulted in pastures with lower NDF (65.97\%) and ADF (33.54\%), and higher in vitro dry matter digestibility $(73.48 \%)$ than unirrigated pastures. Nitrogen fertilization produced improvements in pasture structure, associated with higher dry matter yield and bromatological quality, while irrigation only produced pastures with lower fiber content and greater digestibility.
\end{abstract}

Key words: Botanical components. Structural components. Overseeding. Temperate pasture.

\footnotetext{
1 Discente, Curso de Graduação em Agronomia, Universidade Tecnológica Federal do Paraná, UTFPR, Dois Vizinhos, PR, Brasil. E-mail: jfilho.1996@alunos.utfpr.edu.br

2 Pós-Doutoranda, PNPD CAPES, UTFPR, Dois Vizinhos, PR, Brasil. E-mail: fabiana.matielo@bol.com.br

3 Profs. Drs., UTFPR, Dois Vizinhos, PR, Brasil. E-mail: adalbertolpaula@utfpr.edu.br; wagparis@yahoo.com.br; luismenezes@ utfpr.edu.br

${ }^{4}$ Discentes, Curso de Graduação em Zootecnia, UTFPR, Dois Vizinhos, PR, Brasil. E-mail: fabricioghinzel@gmail.com; gustavo15planalto@hotmail.com
}

* Author for correspondence 


\section{Resumo}

O objetivo deste trabalho foi avaliar o efeito da irrigação e a adubação nitrogenada sobre a qualidade bromatológica, produção de forragem e a composição botânica e estrutural de pastagens de Tifton 85 (Cynodon sp.) sobressemeadas com aveia preta (Avena strigosa). Foram avaliados quatro tratamentos em um esquema fatorial $2 \times 2$ (irrigado e não irrigado x adubado e não adubado), com três repetições, no delineamento inteiramente casualizado. Em piquetes irrigados o sistema de irrigação foi acionado quando o potencial mátrico do solo atingia o valor igual ou superior a $10 \mathrm{kPa}$ e em piquetes adubados foram aplicados $135 \mathrm{~kg} \mathrm{~N} \mathrm{ha}^{-1}$, dividido em quatro aplicações. Foram avaliadas a massa de forragem no pré e pós pastejo, a produção total de forragem, a composição botânica, estrutural e bromatológica das pastagens. Não foram observadas interação entre os fatores irrigação e adubação nitrogenada para nenhuma das variáveis e nem diferenças significativas para os valores da massa de forragem no pré e pós pastejo e nas porcentagens de folhas e colmo de Tifton. Houve efeito da adubação nitrogenada sobre a produção de forragem, onde proporcionou incremento de $2.626,41 \mathrm{~kg} \mathrm{MS} \mathrm{ha}^{-1}$. Além disso, a adubação proporcionou menor porcentagem de material morto $(6,66 \%)$, maior porcentagem de folhas de aveia $(30,84 \%)$, maior relação folha:colmo $(1,45)$, maior teor de proteína bruta (PB) $(24,13 \%)$, menores teores de fibra em detergente neutro (FDN) $(64,57 \%)$ e fibra em detergente ácido (FDA) $(32,86 \%)$ e maior digestibilidade in vitro da matéria seca $(73,01 \%)$. O uso da irrigação não influenciou a produção total de forragem, porém, proporcionou pastagens com menores teores de FDN $(65,97 \%)$ e FDA $(33,54 \%)$ e maior digestibilidade in vitro da matéria seca $(73,48 \%)$. A adubação nitrogenada proporcionou melhorias na estrutura das pastagens, associadas à maior produção de matéria seca e melhor qualidade bromatológica, enquanto que a irrigação apenas proporcionou pastagens com menores teores de fibras e mais digestíveis.

Palavras-chave: Componentes botânicos. Componentes estruturais. Pastagem temperada.

Sobressemeadura.

\section{Introduction}

Species of the genus Cynodon occupy a prominent position among grasses in animal production systems due to their rapid establishment, good forage production, and high nutritional value. However, in subtropical regions, the production of dry matter of these species is highly variable depending on the time of year, with high productivity during the summer and insufficient production during the winter. Therefore, it is necessary to adopt techniques that maintain the balance between food availability and animal requirements in the fall/ winter period, when the production of these species does not meet the demand for food (SILVA et al., 2012).

Moreira et al. (2005) cite the practice of overseeding summer pastures with winter species as a low cost option to promote increased dry matter production of the pasture. The physical characteristics of the soil are maintained without the need to eliminate the species in the area, which improves the composition of the pasture and allows for the continuous use of the pasture after the end of winter.

Oats and/or ryegrass are the predominant overseeding winter species. According to Oliveira et al. (2005), the use of oats and ryegrass in tropical pastures - in addition to the aforementioned benefits - allows for a reduction in the need for stored and concentrated food, fewer labor needs, and less costly food production. In addition, because they have high nutritional value, the practice of overseeding with these species also enables the use of concentrates with lower protein value (OLIVEIRA et al., 2005), thereby reducing production costs and improving the economic efficiency of the activity.

However, soil $\mathrm{N}$ deficiency and lack of water at some times of the year are factors that may limit 
grass growth and persistence in pasture areas, including overseeded areas. According to Caminha et al. (2010), the use of nitrogen can promote significant changes in the dynamics of tillers, resulting in a higher proportion of young tillers in the pasture. In the same way, irrigation can be considered an important tool to balance the supply and quality of forage, promoting an increase in total forage productivity, a greater leaf:stem ratio, an increase in crude protein content, and greater in vitro digestibility of the dry matter (SANCHES et al., 2015).

However, in the practice of overseeding, because the consortium of species have different habits and requirements in terms of nutritional and climatic factors, the responses to irrigation and nitrogen fertilization can be variable, and there is a need for studies to evaluate such responses. Therefore, the objective of this work was to evaluate the effects of irrigation and nitrogen fertilization on the bromatological quality, forage production, and botanical and structural composition of black oat (Avena strigosa) overseeding of Tifton 85 (Cynodon sp.) pastures.

\section{Material and Methods}

The experiment was conducted from June to September 2015 in an area adjacent to the Experimental Farm of the Federal Technological University of Paraná (UTFPR), Campus Dois Vizinhos, southwest region of Paraná, Brazil $\left(25^{\circ} 44^{\prime} \mathrm{S}, 54^{\circ} 04^{\prime} \mathrm{W}\right)$, with an altitude of 520 m, Nitosoil Red Dystroferric soil type and a mesothermal wet subtropical (Cfa) climate, according to the classification of Köppen (MAAK, 1968), with annual rainfall varying between 1800 and $2000 \mathrm{~mm}$.

An area of 1.5 ha was used, subdivided into twelve paddocks of 0.125 ha, where four treatments were tested in a $2 \times 2$ factorial scheme (irrigated and non-irrigated $\times$ fertilized and non-fertilized) with three replicates, using a completely randomized experimental design.

The experiment was carried out in June 2015 in an area of Tifton 85 pasture, which was cut with a brush cutter close to the soil and then planted with black oat (Avena strigosa) to cultivate IAPAR 61, using $100 \mathrm{~kg}$ seeds $\mathrm{ha}^{-1}$, spaced in $17 \mathrm{~cm}$ lines, at a depth of 3 to $5 \mathrm{~cm}$. In addition to the planting of black oat, basic fertilization was carried out according to the results of a soil analysis, with an application of $333 \mathrm{~kg} \mathrm{ha}^{-1}$ of NPK (8-20-10).

In nitrogen fertilized paddocks, application of urea was performed using a dose of $135 \mathrm{~kg} \mathrm{~N}$ ha $^{-1}$ divided into four applications, which were performed after animal grazing. In the irrigated plots, a sprinkler irrigation system was activated according to the water retention curve of the soil and readings from tensiometers installed in the area, with irrigation occurring when the matric potential reached a value equal to, or higher than, $10 \mathrm{kPa}$. The temperature and precipitation during the experimental period were monitored using data from the Experimental Farm meteorological station, located near the experimental site (Table 1).

Table 1. Rainfall and mean temperature between June and September 2015.

\begin{tabular}{cccccc}
\hline \multirow{2}{*}{ Climate Variables } & \multicolumn{5}{c}{ Months } \\
\cline { 2 - 5 } & June & July & August & September & Mean \\
\hline Mean monthly temperature $\left({ }^{\circ} \mathrm{C}\right)$ & 16 & 16,3 & 19,9 & 20,4 & 18,15 \\
Monthly rainfall $(\mathrm{mm})$ & 140,2 & 329,0 & 53,2 & 142,0 & 166,1 \\
\hline
\end{tabular}


A rotational grazing system was adopted, using entry and exit heights of 30 and $10 \mathrm{~cm}$, respectively. Dairy cattle were used to promote grass rearing, without a standard or fixed stocking rate, and the grazing period did not exceed one day.

Samples from the pasture were randomly collected at three points in each paddock at the time of entry (pre-grazing) and exit (post-grazing) of the animals, using a $0.25 \mathrm{~m}^{2}$ metal square and cutting all the mass present in the area of the square at a height greater than $3 \mathrm{~cm}$ from the ground. These samples were weighed separately and homogenized for the removal of a composite sample. The sample was weighed and oven dried using forced air circulation at $55^{\circ} \mathrm{C}$ for $72 \mathrm{~h}$ and then weighed to determine the dry matter content of the forage. The same sample was ground in a Wiley-type mill with $2 \mathrm{~mm}$ sieve for bromatological analysis. The crude protein content (PB) was evaluated using the Kjeldhal method (AOAC, 1984), neutral detergent fiber (NDF) and acid detergent fiber (ADF) using the fiber partition method proposed by Van Soest (1994), and the in vitro dry matter digestibility coefficient (IVDMD) was assessed according to the methodology of Tilley and Terry (1963).
From the fresh samples collected in the field and the dry matter content of the forage, the pre- and post-grazing forage mass was calculated, using the average of each variable for the whole experimental period as final values. The total forage yield was calculated as the product of the daily accumulation rate and the total number of experimental days.

Another composite sample was taken for the botanical and structural separation of the pasture to determine the participation of the components of each species in the consortium (Tifton leaf, Tifton stem, oat leaf, oat stem) and dead material. From these data, the leaf:stem ratio was calculated from the ratio of total leaves (oat leaf + Tifton leaf) and total stems (oat stem + Tifton stem).

An analysis of variance was conducted and significant differences were tested with a Tukey test performed at $5 \%$ error probability.

\section{Results and Discussion}

No significant differences were observed in preand post-grazing forage mass values (Table 2 ) since heights were predetermined.

Table 2. Pre-grazing and post-grazing forage mass, daily accumulation rate, and total forage production in pastures of Black Oat (Avena strigosa) overgrazed with Tifton 85 (Cynodon spp.) with or without irrigation or nitrogen fertilization.

\begin{tabular}{|c|c|c|c|c|}
\hline \multirow{2}{*}{ Irrigation } & \multicolumn{3}{|c|}{ Fertilizing } & \multirow{2}{*}{$\mathrm{CV}(\%)$} \\
\hline & Fertilized & Not Fertilized & Mean & \\
\hline & \multicolumn{3}{|c|}{ Forage mass in pre-grazing $(\mathrm{kg} \mathrm{DM} \mathrm{ha-1})$} & \multirow{4}{*}{9,18} \\
\hline Irrigated & 3016,79 & 2667,17 & 2841,98 & \\
\hline Not Irrigated & 3025,45 & 2803,25 & 2914,35 & \\
\hline Mean & 3021,12 & 2735,21 & & \\
\hline \multicolumn{5}{|c|}{ Forage mass in post-grazing $(\mathrm{kg} \mathrm{DM} \mathrm{ha-1)}$} \\
\hline Irrigated & 2107,98 & 2064,54 & 2086,26 & \multirow{3}{*}{5,10} \\
\hline Not Irrigated & 2195,19 & 1970,36 & 2082,77 & \\
\hline Mean & 2151,58 & 2017,45 & & \\
\hline \multicolumn{5}{|c|}{ Daily accumulation rate $\left(\mathrm{kg} D M\right.$ ha dia $\left.^{-1}\right)$} \\
\hline Irrigated & 110,08 & 62,72 & 86,40 & \multirow{3}{*}{13,93} \\
\hline Not Irrigated & 89,49 & 65,51 & 77,49 & \\
\hline Mean & $99,78 \mathrm{~A}$ & $64,11 \mathrm{~B}$ & & \\
\hline
\end{tabular}


continuation

\begin{tabular}{|c|c|c|c|}
\hline \multirow[b]{2}{*}{ Irrigated } & \multicolumn{3}{|c|}{ Total forage production $\left(\mathrm{kg} \mathrm{DM} \mathrm{ha}^{-1}\right)$} \\
\hline & 7616,65 & 4798,94 & 6207,80 \\
\hline Not Irrigated & 7186,70 & 4751,61 & 5969,15 \\
\hline Mean & $7401,68 \mathrm{~A}$ & $4775,27 \mathrm{~B}$ & \\
\hline
\end{tabular}

*Means followed by different lowercase letters in the columns and upper case in the lines, differ by Tukey's test at a 5\% probability of error.

A higher daily accumulation rate of dry matter and, consequently, a higher total forage yield was observed in the pastures that received nitrogen fertilization $\left(2626.41 \mathrm{~kg} \mathrm{DM} \mathrm{ha}^{-1}\right.$ higher in fertilized pastures than in unfertilized pastures). Irrigation produced no significant differences $(\mathrm{P}>0.05)$ in dry matter accumulation or total forage production (Table 2). These results characterize the beneficial effects and essentiality of nitrogen; this nutrient is part of many of the biomolecules important to plant metabolism, such as ATP, NADH, NADPH, chlorophyll, proteins, and numerous enzymes, but is limited in many production systems (MIFLIN; LEA, 1976; HARPER, 1994; BREDEMEIER; MUNDSTOCK, 2000).

According to Lemaire and Agnusdei (1999), when nitrogen and carbon requirements for leaf growth are met, plants respond positively by activating a greater number of meristems, which results in increased tillering, leaf growth, and central tillering; hence, there is a greater accumulation of biomass. The higher accumulation rate observed in our study in pastures receiving nitrogen than in unfertilized pastures resulted in a shorter rest period (14 vs 25 days) and consequently a higher number of grazing days (5 vs 3 grazing days).

Lupatini et al. (1998) affirmed that a utilization of $150 \mathrm{~kg} \mathrm{~N} \mathrm{ha}^{-1}$ can result in an increase of up to $122 \%$ in the rate of accumulation of pasture dry matter. In addition, according to Cassol et al. (2011), the use of nitrogen to produce an increase in dry matter makes it possible to anticipate the entry of grazing animals, promoting better pasture utilization and higher productivity.
Regarding the use of irrigation, and the benefits generated by this management practice, higher forage production was expected in the irrigated paddocks compared to the non-irrigated paddocks. However, frequent rainfall was observed (Table 1), so the rainfall alone was sufficient to guarantee a water supply to the plants during the experimental period.

According to Martha Júnior (2003), an increase in forage production with the use of irrigation is generally noticed during periods of drought, transitions between periods of drought and rainfall, and also when there is an occurrence of drought during the rainy season, which did not happen during the experiment.

Some botanical and structural components were influenced by the treatments applied (Table 3). There was a higher percentage of oat leaves in the pastures that received nitrogen fertilization, which produced the equivalent of $1015.8 \mathrm{~kg}$ DM more oat leaves per hectare than non-fertilized pastures. The higher yield of oat leaves is attributed to the positive effects of nitrogen through greater accumulation of biomass and changes in tiller dynamics, which resulted in a higher proportion of young tillers in the pasture (CAMINHA et al., 2010; CASSOL et al., 2011) and generated a higher proportion of leaves. In addition, according to Pellegrini et al. (2010), a high percentage of leaves is also a result of the influence of nitrogen acting in zones of stretching and cell division, causing an increase in the number of cells and favoring the expansion and appearance of leaves. 
Higher values for oat stems were observed in non-irrigated pastures than in irrigated pastures, however, this variable was not influenced by nitrogen fertilization (Table 3). Although there were no significant differences in the proportion of Tifton stems and leaves in the botanical composition of the pastures, it is possible that in non-irrigated pastures, the lower percentage of these components, when analyzed together, allowed for the formation of a less dense canopy, resulting in lower competition with the oat plants and allowing greater development of the stalks. When evaluating the competitive effect between oat and vetch plants in a consortium under different sowing densities, Farias Filho et al. (2016) observed a linear decrease in the fresh mass and dry mass of oat stalks as the number of vetch plants increased in the consortium; the larger plant population, by forming a denser canopy, reduced the available area and increased competition for environmental resources, negatively affecting the development of the oat plants.

Table 3. Botanical composition, structural composition, and leaf:stem ratio in pre-grazed pastures of Black Oat (Avena strigosa) overgrazed with Tifton 85 (Cynodon spp.) with or without irrigation or nitrogen fertilization.

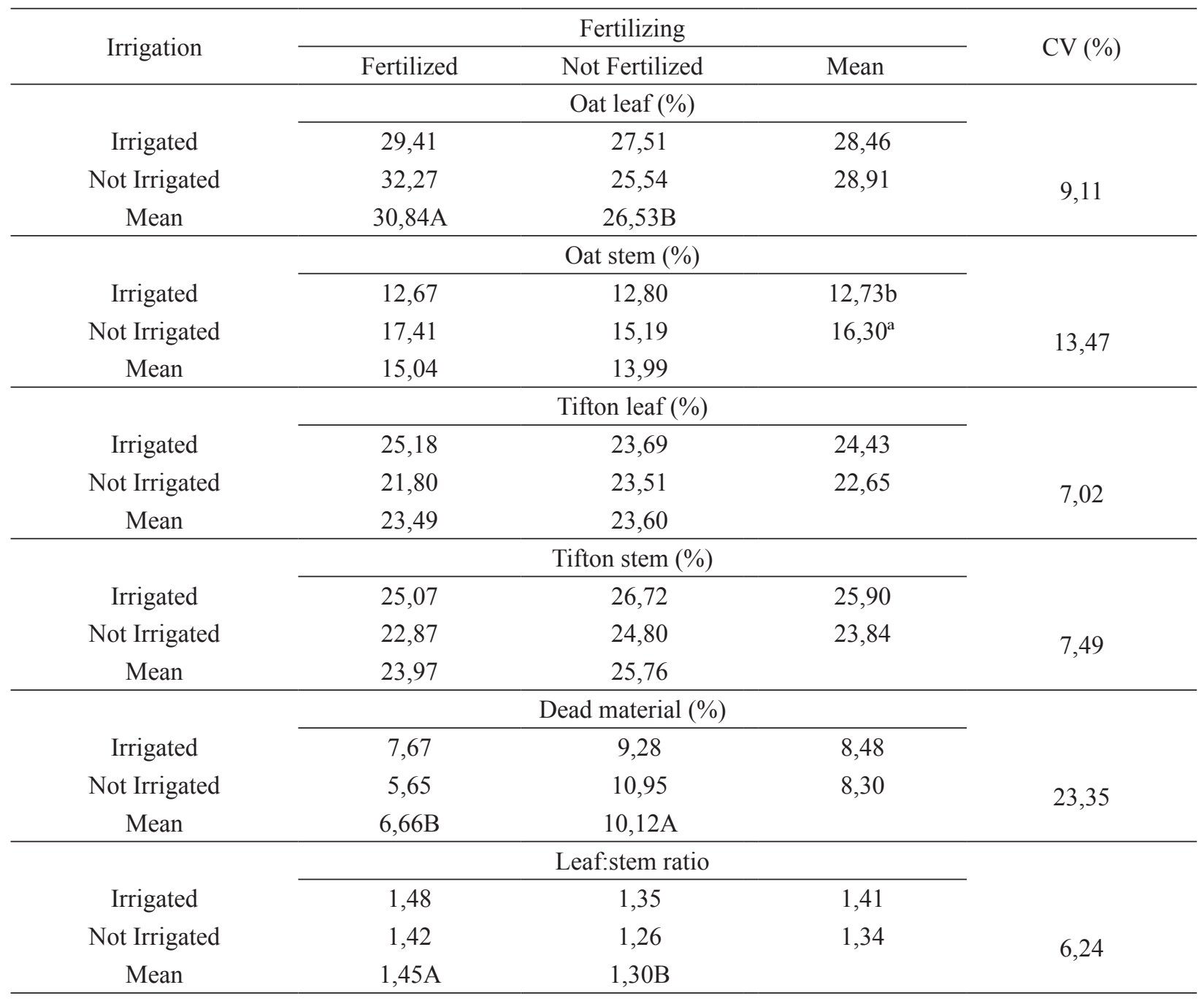

* Means followed by different lowercase letters in the columns and upper case in the lines, differ by Tukey's test at a 5\% probability of error. 
No statistical differences were observed in the leaf and stem components of Tifton between the treatments (Table 3). It was expected that with the application of nitrogen, higher production of Tifton leaves would occur, as observed by Quaresma et al. (2011) and Ribeiro and Pereira (2011), since the use of nitrogen in Tifton 85 grass can promote an increase in the rate of leaf appearance and elongation and greater recovery of leaf area in a short period of time (PEREIRA et al., 2011). However, it is possible that the response of this species to nitrogen was not evident in this experiment because the evaluation was performed during the winter period, when the summer grass responses are generally smaller compared to the summer period due to the lower temperature and shorter photoperiod (CECATO et al., 2001).

The proportion of dead material was higher $(\mathrm{P}<0.05)$ in pastures that did not receive nitrogen fertilization, but there was no significant difference with irrigation use and no significant interaction between the two evaluated factors (Table 3). Nitrogen is a nutrient capable of causing significant changes in the dynamics of tillering and death and in the morphogenic characteristics of forage plants, which, although not evaluated in this work, could explain the differences in the dead material content between fertilized and non-fertilized pastures. Nitrogen produces an increase in leaf lifespan and reduces the rate of leaf senescence since its use maintains the photosynthetic capacity of younger leaves for a longer period, without the element being remobilized from older leaves, causing them to die (GARCEZ NETO et al., 2002; PEREIRA et al., 2011). Therefore, leaf senescence is often associated with N deficiency (MARENCO; LOPES, 2009).

Regarding the leaf:stem ratio, no significant differences were observed with the use of irrigation, however, higher values were obtained in paddocks that received nitrogen fertilization (Table 3). These results are due to the higher production of leaves and lower production of stems in fertilized pastures since this variable is directly proportional to the quantity of leaves and inversely proportional to the quantity of stems.

The crude protein content was higher in pastures that received nitrogen fertilization than in unfertilized pastures, and there was no difference with irrigation use (Table 4). These results evidence a positive effect of nitrogen use to improve forage quality as a result of a metabolic process where available nitrogen is reduced to the ammoniacal form and assimilated into the carbon skeletons through the cycle of glutamic acid and glutamine, being a precursor of several amino acids that form proteins in a specific process called "all or none" (MALAVOLTA; MORAES, 2007; VITOR et al., 2009).

Table 4. Chemical composition in pastures of Black Oat (Avena strigosa) overgrazed with Tifton 85 (Cynodon spp.) with or without irrigation or nitrogen fertilization.

\begin{tabular}{ccccc}
\hline \multirow{2}{*}{ Irrigation } & \multicolumn{3}{c}{ Fertilizing } & \multirow{2}{*}{ CV (\%) } \\
\cline { 2 - 4 } & Fertilized & Not Fertilized & Mean \\
\cline { 2 - 4 } Irrigated & 24,24 & Crude protein (\%) & \\
Not Irrigated & 24,02 & 19,52 & 21,88 \\
Mean & $24,13 \mathrm{~A}$ & 19,06 & 22,04 \\
& \multicolumn{3}{c}{ Neutral detergent fiber (\%) } \\
Irrigated & 63,84 & 68,10 & $65,97 \mathrm{~b}$ \\
Not Irrigated & 65,29 & 71,80 & $68,56 \mathrm{a}$ & 2,42 \\
Mean & $64,57 \mathrm{~B}$ & $69,95 \mathrm{~A}$ & \\
\hline
\end{tabular}




\begin{tabular}{|c|c|c|c|c|}
\hline \multirow[b]{2}{*}{ Irrigated } & \multicolumn{3}{|c|}{ Acid detergent fiber $(\%)$} & \multirow{4}{*}{2,80} \\
\hline & 32,34 & 34,73 & $33,54 b$ & \\
\hline Not Irrigated & 33,37 & 36,93 & $35,15 \mathrm{a}$ & \\
\hline \multirow[t]{2}{*}{ Mean } & $32,86 \mathrm{~B}$ & $35,83 \mathrm{~A}$ & & \\
\hline & \multicolumn{3}{|c|}{ In vitro dry matter digestibility (\%) } & \\
\hline Irrigated & 74,80 & 72,15 & $73,48 \mathrm{a}$ & \\
\hline Not Irrigated & 71,21 & 66,59 & $68,93 b$ & 1,74 \\
\hline Mean & $73,01 \mathrm{~A}$ & $69,40 \mathrm{~B}$ & & \\
\hline
\end{tabular}

*Means followed by different lowercase letters in the columns and upper case in the lines, differ by Tukey's test at a 5\% probability of error.

The levels of NDF (neutral detergent fiber) and ADF (acid detergent fiber) varied with irrigation and fertilization, and were lowest in irrigated pastures and in fertilized pastures (Table 4). By producing higher leaf yields, and consequently a higher leaf:stem ratio, the use of nitrogen promoted the production of less fibrous components, since the use of this nutrient stimulates the appearance of new tissues that have lower levels of structural carbohydrates and lignin in the dry matter (CORSI, 1984; VITOR et al., 2009). On the other hand, the higher fiber content in the non-irrigated paddocks was probably due to the higher production of oats in the absence of irrigation.

As a consequence of the lower fiber content in the presence of nitrogen fertilization and irrigation than in unfertilized and non-irrigated pastures, in vitro digestibility of dry matter was highest in fertilized and irrigated paddocks (Table 4). Both nitrogen fertilization and irrigation can promote better forage DM digestibility as a response to canopy formation with greater leaf participation and lower fiber and cell wall contents, as observed by Sanches et al. (2015) in studies with Tifton 85 grass irrigated and overgrown with oat. In this study, even though there was no irrigation response in terms of leaf percentage, there were fewer oat stalks in irrigated paddocks than in non-irrigated paddocks, which resulted in lower fiber content and higher dry matter in vitro digestibility.

\section{Conclusions}

In the present study, nitrogen fertilization proved to be more efficient than irrigation for improving the structure of oat pastures overgrown with Tifton; fertilized pastures were more productive and of better quality than those that were not fertilized. Irrigation resulted in Tifton 85 pastures overseeded with oat that were more digestible than non-irrigated pastures.

\section{References}

ASSOCIATION OF OFFICIAL AGRICULTURE CHEMISTS - AOAC. Official methods of analyses. $12^{\text {th }}$ ed. Washington: AOAC International, 1984. 1015 p.

BREDEMEIER, C.; MUNDSTOCK, C. M. Regulação da absorção e assimilação do nitrogênio nas plantas. Ciência Rural, Santa Maria, v. 30, n. 2, p. 365-372, 2000.

CAMINHA, F. O.; SILVA, S. C. da; PAIVA, A. J.; PEREIRA, L. E. T.; MESQUITA, P.; GUARDA, V. D. Estabilidade da população de perfilhos de capimmarandu sob lotação contínua e adubação nitrogenada. Pesquisa Agropecuária Brasileira, Brasília, v. 45, n. 2, p. 213-220, 2010.

CASSOL, L. C.; PIVA, J. T.; BRUGNARA, A.; ASSMAN, A. L. Produtividade e composição estrutural de aveia e azevém submetidos a épocas de corte e adubação nitrogenada. Revista Ceres, Viçosa, MG, v. 58, n. 4, p. 438-443, 2011.

CECATO, U.; SANTOS, G. T.; MACHADO, M. A.; GOMES, L. H.; DAMACENO, J. C.; JOBIM, C. C.; RIBAS, N. P.; MIRA, R. T.; CANO, C. C. P. Avaliação de cultivares do gênero Cynodon com e sem nitrogênio. 
Acta Scientiarum, Maringá, v. 23, n. 4, p. 781-788, 2001.

CORSI, M. Effects of nitrogen rates and harvesting intervals on dry matter production, tillering and quality of the tropical grass Panicum maximum, JACQ. 1984. Thesis (Doctor of Philosophy) - The Ohio State University, Ohio.

FARIAS FILHO, J. A.; MORAES, P. V. D.; ARTUSO, V. A.; DAL CHIAVON, J. A.; SILVA, D. W. da; KUNZ, A. G.; ZANINI, W. Competitive effect between black oat (Avena strigosa) and common vetch (Vicia sativa) plants in consortium under diverse populational densities. Journal of Agronomy, Faisalabad, v. 15, n. 4, p. 184-190, 2016.

GARCEZ NETO, A. F.; NASCIMENTO JÚNIOR, D.; REGAZZI, A. J.; FONSECA, D. M.; MOSQUIM, P. R.; GOBBI, K. F. Respostas morfogênicas e estruturais de Panicum maximum cv. Mombaça sob diferentes níveis de adubação nitrogenada e alturas de corte. Revista Brasileira de Zootecnia, Viçosa, MG, v. 31, n. 5, p. 18901900, 2002.

HARPER, J. E. Nitrogen metabolism. In: BOOTE, K. J.; BENNETT, J. M.; SINCLAIR, T. R.; PAULSEN, G. M. Physiology and determination of crop yield. Madison: ASA/CSSA/SSSA, 1994. p. 285-302.

LEMAIRE, G.; AGNUSDEI, M. Leaf tissue turn-over and efficiency of herbage utilization. In: INTERNATIONAL SYMPOSIUM GRASSLAND ECOPHSIOLOGY AND GRAZING ECOLOGY, 1999, Curitiba. Anais... Curitiba: UFPR, 1999. p. 165-186.

LUPATINI, G. C.; RESTLE, J.; CERETTA, M.; MOOJEN, E. L.; BARTZ, H. Avaliação da mistura de aveia preta e azevém sob pastejo submetida a níveis de nitrogênio. I - Produção e qualidade de forragem. Pesquisa Agropecuária Brasileira, Brasília, v. 33, n. 11, p. 1939-1943, 1998.

MAAK, R. Geografia física do Estado do Paraná. Curitiba: Banco de Desenvolvimento do Paraná, 1968. $350 \mathrm{p}$.

MALAVOLTA, E; MORAES, M. F. Fundamentos do nitrogênio e do enxofre na nutrição mineral das plantas cultivadas. In: YAMADA, T.; ABDALLA, S. R. S.; VITTI, G. C. (Ed.). Nitrogênio e enxofre na agricultura brasileira. Piracicaba: International Plant Nutrition Institute, 2007. p. 189-249.

MARENCO, R. A.; LOPES, N. F. Fisiologia vegetal. 3. ed. Viçosa, MG: Editora UFV, 2009. 486 p.

MARTHA JÚNIOR, G. B. Produção de forragem $e$ transformações do nitrogênio do fertilizante em pastagem irrigada de capim Tanzânia. 2003. Tese (Doutorado em
Agronomia) - Escola Superior de Agricultura Luiz de Queiroz, Universidade de São Paulo, Piracicaba.

MIFLIN, B. J.; LEA, P. J. The pathway of nitrogen assimilation in plants. Phytochemistry, New York, v. 15, n. 6, p. $873-885,1976$.

MOREIRA, A. L.; REIS, R. A.; SIMILI, F. F.; PEDREIRA, M. S.; GOMIDE, C. A. M.; RUGGIERI, A. C.; SILVEIRA, R. N. Efeito da sobressemeadura de forrageiras de inverno em pasto de capim-Tifton 85 na disponibilidade de massa seca e composição botânica da forragem. Boletim de Indústria animal, Nova Odessa, v. 62, n. 3, p. 251-264, 2005.

OLIVEIRA, P. P. A.; PRIMAVESI, A. C.; CAMARGO, A. C. de; RIBEIRO, W. M.; SILVA, E. T. M. da. Recomendação da sobressemeadura de aveia forrageira em pastagens tropicais e subtropicais irrigadas. São Carlos: EMBRAPA Pecuária Sudeste, 2005. 7 p. (Comunicado técnico, 61).

PELLEGRINI, L. G.; MONTEIRO, A. L. G.; NEUMANN, M.; MORAES, A.; PELLEGRIN, A. C. R. S.; LUSTOSA, S. B. C. Produção e qualidade de azevémanual submetido a adubação nitrogenada sob pastejo por cordeiros. Revista Brasileira de Zootecnia, Viçosa, MG, v. 39, n. 9, p. 1894-1904, 2010.

PEREIRA, O. G.; ROVETTA, R.; RIBEIRO, K. G.; SANTOS, M. E. R.; FONSECA, D. M.; CECON, P. R. Características morfogênicas e estruturais do capimtifton 85 sob doses de nitrogênio e alturas de corte. Revista Brasileira de Zootecnia, Viçosa, MG, v. 40, n. 9, p. 1870-1878, 2011.

QUARESMA, J. P. S.; ALMEIDA, R. G.; ABREU, J. G.; CABRAL, L. S.; OLIVEIRA, M. A.; CARVALHO, D. M. G. Produção e composição bromatológica do capimtifton 85 (Cynodon spp.) submetido a doses de nitrogênio. Acta Scientiarum. Animal Sciences, Maringá, v. 33, n. 2, p. 145-150, 2011.

RIBEIRO, K. G.; PEREIRA, O. G. Produtividade de matéria seca e composição mineral do capim-tifton 85 sob diferentes doses de nitrogênio e idades de rebrotação. Ciência e Agrotecnologia, Lavras, v. 35, n. 4, p. 811-816, 2011.

SANCHES, A. C.; GOMES, E.; RICKLI, M.; FASOLIN, J.; SOARES, M.; GOES, R. Produtividade e valor nutritivo do capim Tifton 85 irrigadoe sobressemeado com aveia. Revista Brasileira de Engenharia Agrícola e Ambiental, Campina Grande, v. 19, n. 2, p. 126-133, 2015.

SILVA, C. E. da; MENEZES, L. F. G.; ZIECH, M. F.; KUSS, F.; RONSANI, R.; BIESEK, R. R.; BOITO, B.; 
LISBINSKI, E. Sobressemeadura de cultivares de aveia em pastagem de estrela africana manejada com diferentes resíduos de forragem. Semina: Ciências Agrárias, Londrina, v. 33, n. 6, p. 2441-2450, 2012.

TILLEY, J. M. A.; TERRY, R. A. A two stage technique for the in vitro digestion of forage crop. Journal of Britain Grassland Society, Kenilworth, v. 18, n. 2, p. 104-111, 1963.
VAN SOEST, P. J. Nutritional ecology of the ruminant. $2^{\text {th }}$ ed. Ithaca: Cornell University Press, 1994. 476 p.

VITOR, C. M. T.; FONSECA, D. M.; CÓSER, A. C.; MARTINS, C. E.; NASCIMENTO JÚNIOR, D.; RIBEIRO JÚNIOR, J. I. Produção de matéria seca e valor nutritivo de pastagem de capim-elefante sob irrigação e adubação nitrogenada Revista Brasileira de Zootecnia, Viçosa, MG, v. 38, n. 3, p. 435-442, 2009. 